\title{
RADIOCARBON AGE PROFILES AND SIZE DEPENDENCY OF MIXING IN NORTHEAST ATLANTIC SEDIMENTS
}

\author{
Louise Brown ${ }^{1,2} \bullet$ Gordon T Cook $^{1} \bullet$ Angus B MacKenzie ${ }^{1}$ John Thomson ${ }^{3}$
}

\begin{abstract}
In recent years, the most common technique for radiocarbon dating of deep-ocean sediments has been accelerator mass spectrometry (AMS) analysis of hand-picked planktonic foraminifera (forams). Some studies have exposed age offsets between different sediment size fractions from the same depth within a core and this has important implications when establishing a chronological framework for palaeoceanographic records associated with a particular sediment component. The mechanisms generating the age offsets are not fully understood, a problem compounded by the fact that the fraction defined as "large" varies between different studies. To explore this problem, we dated samples of hand-picked forams from two Biogeochemical Ocean Flux Study (BOFS) cores, for which the presence of an offset between the bulk carbonate and $>150 \mu \mathrm{m}$ foraminiferal calcite had already been demonstrated. The presence of a constant age offset between bulk carbonate and coarse fraction material at the two BOFS sites has been confirmed, but the magnitude of the offset is dependent on whether a simple size-separation technique or hand-picking of well-preserved forams is applied. This may be explained if the selection of well preserved forams biases the sample towards those specimens that have spent least time in the surface mixed layer (SML) or have undergone less size selective mixing. Modeling of the ${ }^{14} \mathrm{C}$ profiles demonstrates that SML depth and sediment accumulation rates are the same for both the bulk and coarse sediment fractions, which is consistent with the hypothesis that size-selective mixing is responsible for the age offset.
\end{abstract}

\section{INTRODUCTION}

The isotopic and chemical composition of foraminiferal tests from deep-sea sediments may be used to derive information on past oceanographic and climatic conditions, including temperature (Emiliani 1955), pH (Sanyal et al. 1995), nutrient concentration (Boyle 1988; Lea and Boyle 1990), and ocean circulation (Broecker et al. 1984). In parallel with these measurements, radiocarbon dating of the sediment may be used to determine a direct chronological framework for environmental change over the past 50,000 years, as well as defining sediment accumulation rates, bioturbation depths, and other parameters required to model long-term sedimentary processes. In many studies, accelerator mass spectrometry (AMS) ${ }^{14} \mathrm{C}$ dating of samples of large (usually $>150 \mu \mathrm{m}$ ) planktonic foraminifera (forams) has been employed as a means of circumventing the problem of current-redistributed carbonate which will increase the age of a sediment horizon (e.g. Berger et al. 1985; Broecker et al. 1988). The large planktonic forams are less prone to current redistribution than fine sediment and have a fixed initial reservoir age (unlike benthic carbonate-skeletoned organisms) so that dating only planktonic foram material should constrain the ${ }^{14} \mathrm{C}$ chronology more tightly.

It has long been known that the resolution of sedimentary records is blurred by biological mixing of the surface mixed layer (SML). Models of increasing complexity have evolved to reconstruct the unbioturbated record, taking into account mixing depth, sedimentation rate (Berger and Heath 1968; Erlenkeuser 1980) and, for AMS dating of forams, effects incurred by species abundance changes (Schiffelbein 1984; Bard et al. 1987; Manighetti et al. 1993) or dissolution (Peng and Broecker 1984). These models apply uniform rates and mechanisms of mixing to all sediment components, but ${ }^{14} \mathrm{C}$ dating of different components of deep-sea sediment has yielded significant age offsets between size fractions that may vary in both direction and magnitude (Figure 1). The cause of these offsets is not fully understood, yet knowledge of the processes involved is vital if accurate chronologies for palaeoclimatic and palaeoceanographic records are to be achieved.

${ }^{1}$ Scottish Universities Research and Reactor Centre, Scottish Enterprise Technology Park, Rankine Avenue, East Kilbride, G75 0QF, United Kingdom

${ }^{2}$ Corresponding author. Email: L.Brown@ surrc.gla.ac.uk.

${ }^{3}$ Southampton Oceanography Centre, Empress Dock, Southampton, SO14 7ZH, United Kingdom

(C) 2001 by the Arizona Board of Regents on behalf of the University of Arizona

RadiocarBon, Vol 43, Nr 2B, 2001, p 929-937

Proceedings of the 17 th International ${ }^{14} \mathrm{C}$ Conference, edited by I Carmi and E Boaretto 


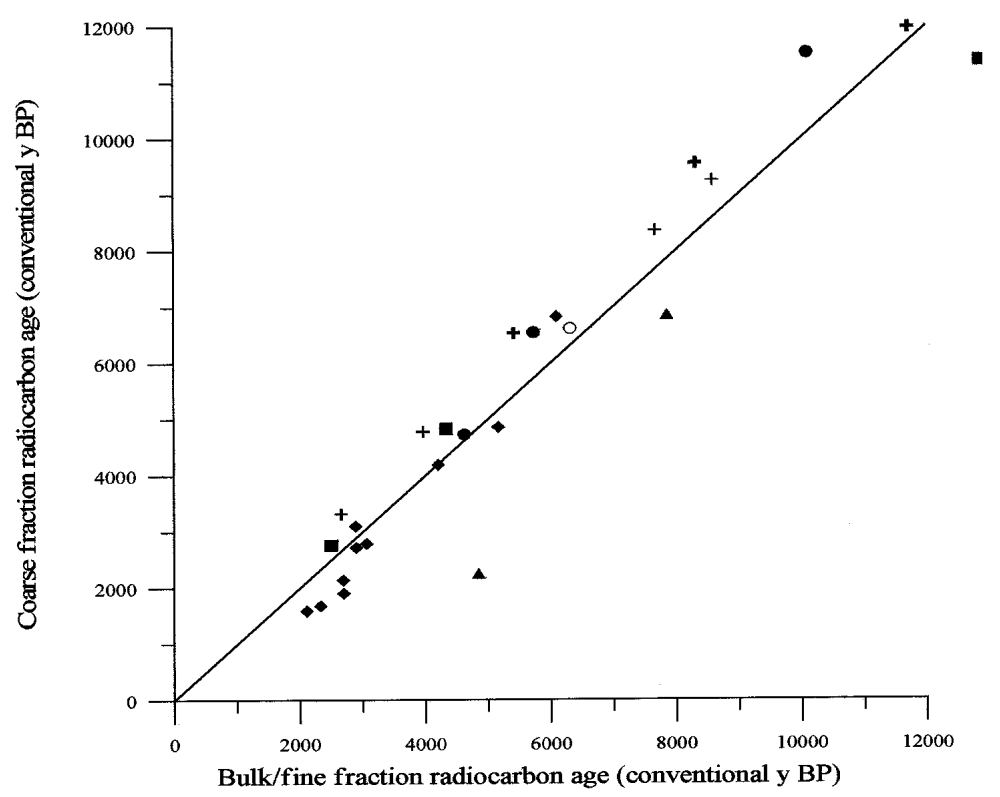

Figure 1 Examples of Holocene-age size fraction ${ }^{14} \mathrm{C}$ age offsets found in previous studies. Data are taken from the following sources: $\boldsymbol{+}=$ Thomson et al. 1995; $\bullet=$ Brown et al. 2000; $\boldsymbol{\square}=$ Jones et al. 1989; $\bullet=$ Paull et al. 1991; $\boldsymbol{\Delta}=$ Berger et al. 1985; O = Andree et al. 1984. Additional offsets have also been reported for older sediments.

A further complicating factor is that the component classified as "large" in such studies differs widely, ranging from single-species forams (Paull et al. 1991), to bulk sieved carbonate from a particular size fraction (Andree et al. 1984; Berger et al. 1985; Jones et al. 1989) with intermediate variations, including polyspecific forams (Brown et al. 2000) and planktonic foraminiferal calcite (Thomson et al. 1995). This presents problems when comparing data from different studies and determining the relative impact of different mechanisms in generating the age offset.

One study directly addressing the problem of size fraction induced age offsets is that of Thomson et al. (1995) at two sites from the United Kingdom Biogeochemical Ocean Flux Study (BOFS). They analyzed material which was wet sieved to $>150 \mu \mathrm{m}$ and from which benthic forams, ash fragments and lithic debris were removed, leaving a sample of essentially planktonic foraminiferal calcite. Samples prepared in this way were found to be consistently older than bulk carbonate from the same depth. This is the opposite effect of the effect expected from a current-redistributed carbonate input, and the age range and water depth were such that bioturbation-abundance or bioturbation-dissolution effects were unlikely to be the cause of the offset. The use of polyspecific samples and fractionation correction by means of stable isotope measurements should ensure that small-scale carbon isotope fractionation or species vital effects would be accounted for. Thomson et al. (1995) concluded that the remaining possibility was particle-size induced differential mixing by benthic organisms - a mechanism also used to explain the presence of "lag layers" of coarse $(>2 \mathrm{~mm}$ ) particles derived from a glacial gravel sediment found in a mud deposit several centimeters above the original horizon of deposition (McCave 1988). In essence, this hypothesis proposes that mixing ceases to be completely random when burrowing organisms encounter large sediment grains, as less energy is required to move such grains upwards than to push them downwards, whilst fine sediment then falls into the void thus created. If this mechanism is applicable to the coarse grained foram fraction of deep-sea sediment, dif- 
fering rates of transport out of the SML for the fine and coarse fractions will result in an age offset. In contrast, at the nearby Benthic Boundary Layer Experiment (BENBO) sites, samples of $>150 \mu \mathrm{m}$ hand-picked polyspecific planktonic forams were found to be younger than the bulk carbonate in the upper mixed layer, but approximately the same age as the bulk below about $10 \mathrm{~cm}$. This age offset was attributed either to the different coarse fraction sampling methods employed in the two studies, or different bioturbational processes found at this site as a result of its shallower water depth and higher $\mathrm{C}_{\text {org }}$ flux (Brown et al. 2000).

The aim of the present study is to evaluate the effect of sample selection method on the radiocarbon age offset found between the coarse size fraction and bulk sediment of the BOFS cores, where the offset-producing mechanism is already accounted for by size-differential mixing. We also extended the measurements into the SML in the hope of gaining some knowledge of the processes generating the offset at the BOFS sites.

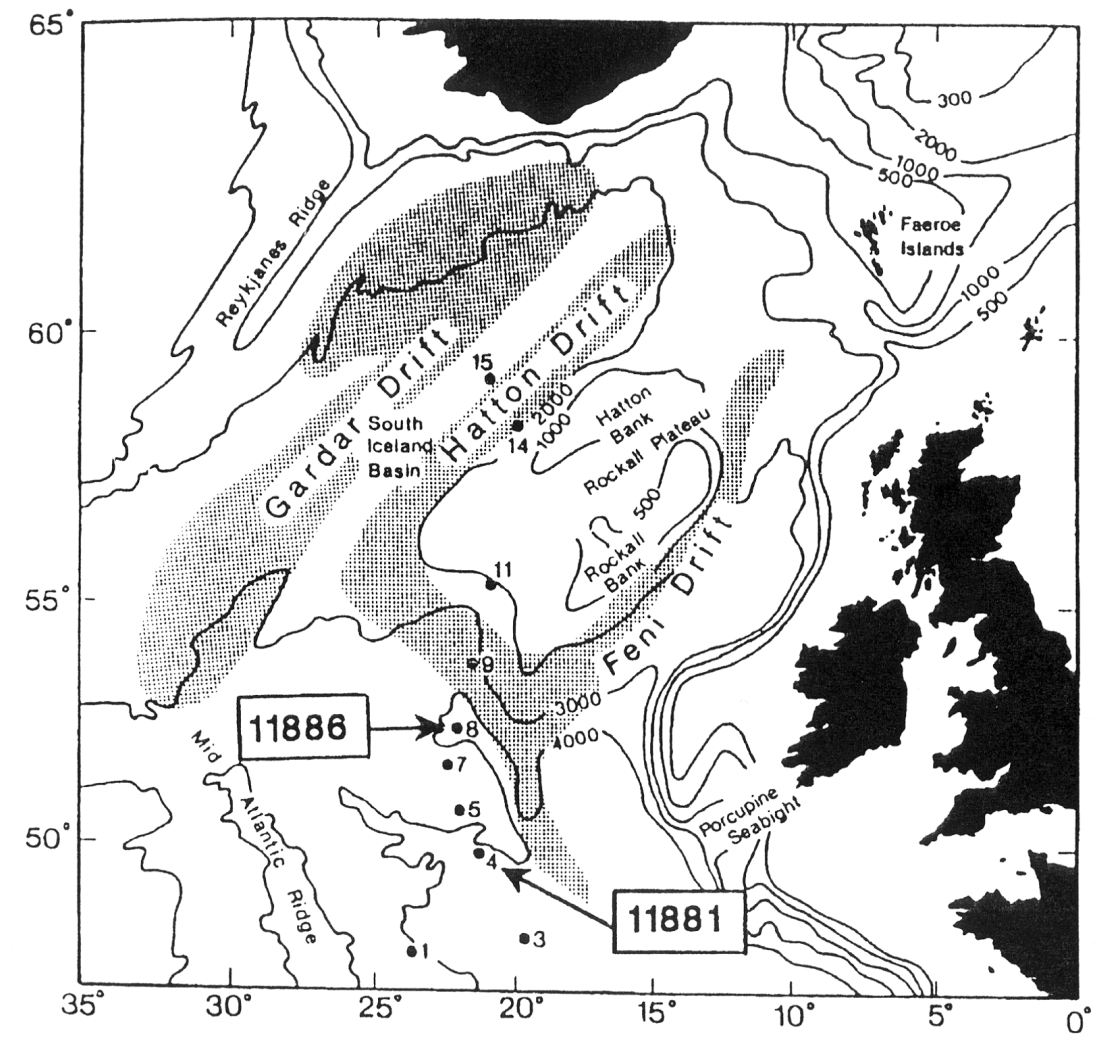

Figure 2 Map of northeast Atlantic Ocean, highlighting BOFS stations 4 (core 11881) and 8 (core 11886)

\section{METHODS}

This study used archived material from box cores 11881 and 11886 collected from stations 4 and 8 (Figure 2) of the UK BOFS study. The cores were collected from $4000 \mathrm{~m}$ water depth, from a relatively rapidly accumulating site $\left(5.9 \mathrm{~cm} \mathrm{ka}^{-1}\right)$ on the northern flank of the East Thulean Rise (11886), and a more slowly accumulating site $\left(3.0 \mathrm{~cm} \mathrm{ka}^{-1}\right)$ on the southern flank of the rise. A full 
description of the BOFS study area can be found in Thomson et al (1993). The box cores had been sub-cored and sectioned into 1-cm thick slices and stored frozen. Five 1-cm depth increments were chosen from another sub-core from BOFS sites 11881 and 11886, to include material from both above and below the SML. The sediment was dried at $50^{\circ} \mathrm{C}$ and disaggregated in $200 \mathrm{~mL}$ deionized water, before wet sieving into $<150 \mu \mathrm{m}$ and $>150 \mu \mathrm{m}$ size fractions using additional deionized water. Samples of 12-25 mg of well-preserved polyspecific planktonic forams were hand picked from the $>150 \mu \mathrm{m}$ size fraction. Graphite targets were prepared from $\mathrm{CO}_{2}$ produced by acid hydrolysis of the samples (Slota et al. 1987), and analyzed by AMS at the NSF-Arizona AMS facility.

Large (50 mg) samples of forams were hand-picked from BOFS core 11881 at 1-2 cm and 26-27 cm depths for a simple pretreatment experiment. This involved splitting the samples so that $12 \mathrm{mg}$ were used to prepare graphite targets as above, whilst the remainder were pretreated with sufficient $0.16 \mathrm{M}$ $\mathrm{HCl}$ to remove the outer $20 \%$ carbonate. The $\mathrm{CO}_{2}$ gas generated by addition of the $0.16 \mathrm{M} \mathrm{HCl}$ was also collected and graphitized, in order to estimate the age of the material removed by the leaching.

Table 1 New AMS ${ }^{14} \mathrm{C}$ data for polyspecific hand picked planktonic foraminifera from BOFS cores 11881 and 11886 . All ages reported are conventional radiocarbon years BP.

\begin{tabular}{llcc}
\hline Lab code & Sample ID & ${ }^{14}$ C age (BP) & $1 \sigma$ error \\
\hline BOFS core 11881 & Polyspecific Forams & & \\
GU-8740 & BOFS 11881 0.0-1.0 cm & 3630 & 40 \\
GU-8741 & BOFS 11881 4.0-5.0 cm & 3610 & 45 \\
GU-8742 & BOFS 11881 10.0-11.0 cm & 4900 & 45 \\
GU-8743 & BOFS 11881 19.0-20.0 cm & 6550 & 50 \\
GU-8744 & BOFS 11881 26.0-27.0 cm & 9630 & 60 \\
BOFS core 11886 & Polyspecific Forams & & \\
GU-8735 & BOFS 11886 1.0-2.0 cm & 2660 & 45 \\
GU-8736 & BOFS 11886 4.0-5.0 cm & 2700 & 40 \\
GU-8737 & BOFS 11886 10.0-11.0 cm & 2710 & 50 \\
GU-8738 & BOFS 11886 19.0-20.0 cm & 4260 & 45 \\
GU-8739 & BOFS 11886 28.0-29.0 cm & 5620 & 45 \\
BOFS core 11881 & Pretreated forams & & \\
GU-8745a & BOFS 11881 0.0-1.0 cm & 55 \\
GU-8745b & BOFS 11881 0.0-1.0 cm $\mathrm{cm}^{\mathrm{b}}$ & 2590 & 50 \\
GU-8746a & BOFS 11881 26.0-27.0 cm & 4180 & 60 \\
GU-8746b & BOFS 11881 26.0-27.0 cm & 10,355 & 60 \\
Standards & TIRI K Turbiditec & 10,085 & \\
GU-8847 & TIRI F Icelandic Doublespard & $>45,000$ & \\
BK-44 & & & \\
\hline Car & & & \\
\hline
\end{tabular}

${ }^{a}$ Carbon removed during pretreatment with $0.16 \mathrm{M} \mathrm{HCl}$

${ }^{b}$ Pretreated forams

cTIRI K turbidite standard consensus age is 18,155 $\pm 34 \mathrm{BP}$ (Gulliksen and Scott 1995).

${ }^{\mathrm{d}}$ TIRI F Icelandic doublespar standard consensus age is 46,750 $\pm 208 \mathrm{BP}$ (Gulliksen and Scott 1995). 


\section{RESULTS AND DISCUSSION}

The ${ }^{14} \mathrm{C}$ ages for the polyspecific planktonic foram samples are listed in Table 1 and illustrated along with the published data for bulk carbonate and foraminiferal calcite (Thomson et al. 1995) in Figure 3. The data from all profiles were modeled after Erlenkeuser (1980) and the parameters derived are presented in Table 2.

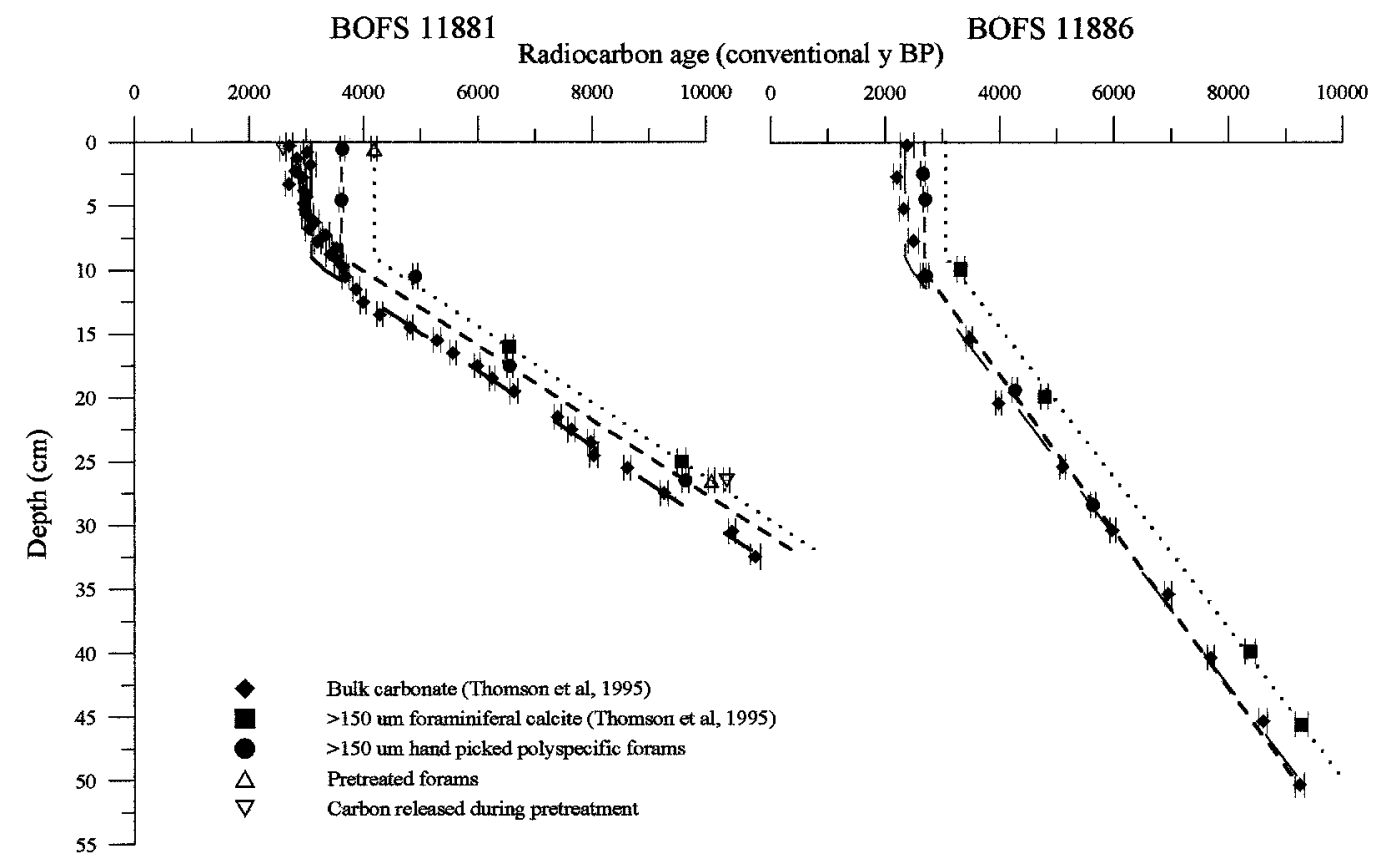

Figure $3{ }^{14} \mathrm{C}$ results for-hand picked polyspecific planktonic foraminifera, shown with the bulk carbonate and foraminiferal carbonate data of Thomson et al. (1995). Solid lines are the bulk carbonate data modeled using the box model of Erlenkeuser (1980), as listed in Table 2.

Table $2{ }^{14} \mathrm{C}$ age-depth profiles for BOFS cores 11881 and 11886 , modeled for each of the three sampling strategies using the parameters outlined in Erlenkeuser (1980). Where fit to data $\left(R^{2}\right)$ is marked *, accumulation rate is based on two points only.

\begin{tabular}{lcccccr}
\hline & $\begin{array}{c}\text { Accum. } \\
\text { rate } \\
\left(\mathrm{cm} \mathrm{ka}^{-1}\right)\end{array}$ & $\begin{array}{c}\text { Fit to } \\
\text { data } \\
\left(\mathrm{R}^{2}\right)\end{array}$ & $\begin{array}{c}\text { SML } \\
\text { depth } \\
(\mathrm{cm})\end{array}$ & $\begin{array}{c}\text { Data } \\
\text { average } \\
\text { SML age } \\
(\mathrm{yr})\end{array}$ & $\begin{array}{c}\text { Calc. } \\
\text { SML age } \\
(\mathrm{yr})\end{array}$ & $\begin{array}{c}\mathrm{T}_{0} \text { age } \\
(\mathrm{yr})\end{array}$ \\
\hline 11881 bulk carbonate & 3.0 & 0.988 & 9.3 & 3090 & - & 370 \\
11881 hand-picked forams & 3.0 & $1.00^{*}$ & 8.9 & 3620 & - & 900 \\
11881 foram. carbonate & 3.0 & $1.00^{*}$ & - & - & 4180 & 1800 \\
11886 bulk carbonate & 5.9 & 0.996 & 9.3 & 2350 & - & 840 \\
11886 hand-picked forams & 6.1 & 0.998 & 10.0 & 2690 & - & 1200 \\
11886 foram. carbonate & 5.9 & 0.998 & - & - & 3060 & 1830 \\
\hline
\end{tabular}




\section{Core 11881}

Omitting the data point at $10-11 \mathrm{~cm}$, the ${ }^{14} \mathrm{C}$ profile for the hand-picked planktonic forams generates the same SML depth and accumulation rate as both the bulk carbonate and foraminiferal calcite profiles of Thomson et al. (1995). However, the hand-picked foram profile is offset from the bulk carbonate profile by $+0.6 \mathrm{ka}$, and from that of the foraminiferal calcite by $-0.5 \mathrm{ka}$. The remaining data point at $10-11 \mathrm{~cm}$, together with the pretreated sample at $26-27 \mathrm{~cm}$, lies on the line described by the two points from the foraminiferal calcite. If we assume an SML of $9 \mathrm{~cm}$, similar to those calculated for the bulk carbonate and hand-picked foram profiles, the age of the pretreated sample at $0-1 \mathrm{~cm}$ is similar to the modeled foraminiferal calcite SML age. The carbon removed during pretreatment of the $0-1 \mathrm{~cm}$ sample is close in age to the bulk carbonate. Recalculating the age of the total sample using the percent modern values reported for the samples $([0.2 \times 0.7244]+[0.8 \times 0.5943])$ gives a value of $3840 \pm 75$, in reasonable agreement with the $3630 \pm 40$ determined for the untreated foram sample. The age of carbon removed during pretreatment of the $26-27 \mathrm{~cm}$ sample is older than the pretreated sample by about 200 years.

\section{Core 11886}

The profile for hand-picked foram data for this core coincides almost exactly with the profile for bulk carbonate, but appears smoother (although this may be simply due to having fewer data points than the bulk profile). The average age of the hand-picked foram SML is 340 years older than that calculated for the bulk carbonate, which makes a minor difference of $0.7 \mathrm{~cm}$ in the calculated depth of the SML.

\section{Modification of Offset}

The reduction in the bulk carbonate/coarse fraction age offset for hand-picked forams compared to that for bulk carbonate/coarse fraction using foraminiferal calcite establishes that the method of sample preparation has some effect on the ${ }^{14} \mathrm{C}$ age determined for a particular depth horizon. The concordance of values for accumulation rate and SML depth also suggests that the offset is the result of a physical process rather than sampling or material heterogeneities, such as differential loss of surface sediment between sub cores or the sampling of material advected down burrow openings.

The selection of whole forams must in some way eliminate a proportion of the forams which have undergone most size-selective mixing. The most obvious reason for this would be on the basis of particle age. In any sediment depth horizon, the particles are composed of a range of ages, depending on the amount of mixing, the SML depth and the sediment accumulation rate. The longer the residence time in the SML, the greater the probability of physical breakage of the foram tests by mixing or by chemical attack. Where both well-preserved and damaged specimens are present in a sample, the damaged specimens are most likely to be rejected by this sampling method.

Another possible explanation is that the size spectrum of particles is shifted by selecting only whole foram tests. McCave (1988) has demonstrated that in the range of foram sizes, the biodiffusion diffusion coefficient varies inversely with grain size. Therefore, if by some means, the smaller, less size-selectively mixed forams are less liable to be damaged by physical mixing than larger specimens, rejection of the large foram fragments would leave a sample of forams from the smaller size range and thus a shorter residence time in the mixed layer. 


\section{Formation of Age Offset}

The homogeneity of the SML data for the hand-picked forams leaves only two possibilities for the origin of the age offset; either the forams are initially older than fine material on initial incorporation into the SML, or their residence time in the mixed box is increased relative to the fine fraction by means of size-selective mixing. Thin-walled, water-filled foraminiferal tests have hydrodynamic properties similar to much smaller grains (Oehmig 1988) and it is possible that some may be resuspended and transported before incorporation into the sediment. However, in the high energy conditions that this would require, at least some fine material should be similarly transported, but the $\mathrm{T}_{0}$ (age of freshly arriving material) for core 11881 bulk carbonate is close to the North Atlantic reservoir age of 400 years (Bard 1988), and demonstrates that this cannot be the case for this site.

There is ample evidence of size-selective mixing mechanisms in the deep-sea environment, in addition to the process observed by McCave (1988). Berger and Johnson (1978) considered the lag between $\delta^{18} \mathrm{O}$ and ${ }^{14} \mathrm{C}$ records to be a consequence of this effect, and radiochemical studies in the deep ocean have shown that radionuclides associated with finer fractions are apparently bioturbated more rapidly than those associated with coarse material (Cochran 1985; DeMaster and Cochran 1982). Evidence from laboratory studies (e.g. Bock and Miller 1999) and statistical studies of the distribution of tektites and coarse-grained volcanic debris in marine sediment (Wheatcroft and Jumars 1989) also point to size-selectivity of mixing. These studies all indicate a slower rate of mixing of coarse material, but at the BOFS sites mixing must still be rapid in comparison to the ${ }^{14} \mathrm{C}$ timescale in order to generate a homogeneous SML for the coarse fraction. By analyzing a number of closely spaced depth increments in core 11881, Thomson et al. (1995) showed that the SML consisted of a well-mixed upper layer $(0-5 \mathrm{~cm})$ overlying a less thoroughly-mixed layer $(5-10 \mathrm{~cm})$. McCave (1988) demonstrated that the preferential upwards movement of coarse material would occur only under certain conditions of sediment accumulation and (diffusive) bioturbation rates, and it may be that this type of mixing occurs only in the well-mixed upper part of the SML of core 11881. This differential mixing by small organisms may occur in the upper $5 \mathrm{~cm}$ of the mixed box, followed by mixing by larger, less size-selective organisms living deeper in the sediment. The outlier at $10-11 \mathrm{~cm}$ in the same core may be an artefact of this bimodal mixing, yet the offset still exists in the SML of 11886 where there is no evidence of this change in bioturbation.

\section{Pretreated Samples}

The effects of modern contamination have been noted on background-age samples of both forams (Schleicher et al. 1998) and coral (Burr et al. 1992). The aim of this pretreatment experiment was to ascertain if contamination from either older or younger carbonates is significant in Holocene-age samples, and whether it could be responsible for the age offset. For the $0-1 \mathrm{~cm}$ sample, the age of the pretreated sample is almost exactly the same as the hypothetical age determined for the SML of foraminiferal calcite, while the age of carbon produced during pretreatment is similar to the age determined for the bulk carbonate at the same depth. This suggests there may be some fine-grained carbonate trapped within the foram tests which is influencing the age of the untreated sample, assuming that this is the material which dissolves more rapidly. If foram tests are whole rather than fragmented, it may be more difficult to remove trapped fine carbonate by simply rinsing with water, as in the procedure employed in both this study and by Thomson et al. (1995). However, while the datum for the pretreated sample from $26-27 \mathrm{~cm}$ depth is also located on the foraminiferal calcite profile, the age of carbon released during pretreatment is older than the sample age. The source of apparent contamination in this case is unclear. The older age of the carbon released during pretreatment means that the cause of the difference between the pretreated and unpretreated samples at this 
depth is also unclear. Sample size and representation should not be an issue as the analyses were carried out on splits from the same $50 \mathrm{mg}$ sample, unless some fractionation of older and younger forams could have occurred during the process of splitting the sample. We discount the possibility of contamination introduced during sample preparation, as a background sample of infinite age marble and a known-age turbidite from the TIRI study (Gulliksen and Scott 1995) which underwent the same procedure as the foram samples yielded satisfactory ages (Table 1). Given the elementary nature of the pretreatment technique, it is unwise to extrapolate too much from a single result, but obviously further work is required in this area.

\section{CONCLUSION}

The presence of a constant age offset between bulk carbonate and coarse fraction material at two BOFS sites has been confirmed, but the magnitude of the offset is dependent on whether a simple size-separation technique or hand-picking of well-preserved forams is applied. This may be explained if the selection of well-preserved forams biases the sample towards those specimens which have spent least time in the SML and undergone less size-selective mixing. The sampling artefacts affecting ${ }^{14} \mathrm{C}$ age cannot be ignored in favour of dating a bulk large size fraction or bulk carbonate, as most foram palaeonvironmental studies are based on one or two species, which have to be fairly wellpreserved in order to be correctly identified. Modeling of the ${ }^{14} \mathrm{C}$ profiles demonstrates that SML depth and sediment accumulation rates are the same for both the bulk and coarse sediment fractions, which is consistent with the hypothesis that size-selective mixing is responsible for the age offset.

Pretreatment of samples by acid hydrolysis results in age differences between treated and untreated samples, both at the sediment surface and at depth. The difference in the upper sample appears to be the result of fine carbonate trapped in the foram tests, but this does not hold for the deeper sample.

\section{ACKNOWLEDGMENTS}

We are indebted to Ms S Nixon (SOC) and Mr P Naysmith (SURRC) for assistance in the laboratory, and to Dr S Wakefield (University of Cardiff) for providing the archived samples. This project was supported by NERC grant GST/03/1762. This is publication number 17 of the Thematic Research Programme BENBO, carried out under award from the UK Natural Environment Research Council.

\section{REFERENCES}

Andree M, Beer J, Oeschger H, Broecker W, Mix A, Ragano N, O’Hara P, Bonani G, Hofman HJ, Morenzoni E, Nessi M, Suter M, Wolfli W. 1984. ${ }^{14} \mathrm{C}$ measurements on foraminifera of deep sea core V28-238 and their preliminary interpretation. Nuclear Instruments and Methods B 5:340-5.

Bard E, Arnold M, Duprat J, Moyes J, Duplessey J-C. 1987. Reconstruction of the last deglaciation: deconvolved records of $\delta^{18} \mathrm{O}$ profiles, micropalaeontological variations and accelerator mass spectrometric ${ }^{14} \mathrm{C}$ dating. Climate Dynamics 1:101-12.

Bard E. 1988. Correction of accelerator mass spectrometry ${ }^{14} \mathrm{C}$ ages measured in planktonic foraminifera: Palaeoceanographic implications. Palaeoceanography 3:635-45.

Berger WH, Johnson RF. 1978. On the thickness and the ${ }^{14} \mathrm{C}$ age of the mixed layer in deep-sea carbonates. Earth and Planetary Science Letters 41:223-7.
Berger WH, Killingly JS, Metzler CV and Vincent E. 1985. Two-step deglaciation: ${ }^{14} \mathrm{C}$-dated high-resolution $\delta^{18} \mathrm{O}$ records from the tropical Atlantic Ocean. Quaternary Research 23:258-71.

Bock MJ. Miller DC. 1999. Particle selectivity, gut volume and the response to a step change in diet for deposit-feeding polychaetes. Limnology and Oceanography 44:1132-8.

Boyle EA. 1988. Cadmium: Chemical tracer of deepwater palaeoceanography. Paleoceanography 3:471-89.

Broecker WS, Mix A, Andree M, Oescher H. 1984. Radiocarbon measurements on coexisting benthic and planktic foraminifera shells: potential for reconstructing ocean ventilation times over the past 20,000 years. Nuclear Instruments and Methods B 5:331-9.

Broecker WS, Andree M, Wolfli W, Oeschger H, Bonani G, Kennet J, Peteet D. 1988. The chronology of the last deglaciation: Implications to the cause of the 
Younger Dryas event. Paleoceanography 3:1-19.

Brown L, Cook GT, MacKenzie AB, Naysmith P, Anderson R, Thomson J, Nixon S. 1999. Characterisation of differential mixing between foraminifera and bulk carbonate in N.E. Atlantic sediments. Nuclear Instruments and Methods $\mathrm{B}$. In press.

Burr GS, Edwards RL, Donahue DJ, Druffel ERM, Taylor FW. 1992. Mass spectrometric ${ }^{14} \mathrm{C}$ and U-Th measurements in coral. Radiocarbon 34(3):611-8.

Cochran JK. 1985. Particle mixing rates in sediments of the eastern equatorial Pacific: evidence from ${ }^{210} \mathrm{~Pb}$, ${ }^{239,240} \mathrm{Pu}$ and ${ }^{137} \mathrm{Cs}$ distributions. Geochimica et Cosmochimica Acta 49:1195-210.

DeMaster DJ, Cochran JK. 1982. Particle mixing rates in deep sea sediments determined from excess ${ }^{210} \mathrm{~Pb}$ and ${ }^{32} \mathrm{Si}$ profiles. Earth and Planetary Science Letters 61: $257-81$.

Emiliani C. 1955. Pleistocene temperatures. Journal of Geology 63:538-78.

Erlenkeuser H. 1980. ${ }^{14} \mathrm{C}$ age and vertical mixing of deep sea sediments. Earth and Planetary Science Letters 47:319-26.

Gulliksen S, Scott EM. 1995. Report on the TIRI workshop. Radiocarbon 37(2):820-1.

Jones GA, Jull AJT, Linick TW, Donahue DJ. 1989. Radiocarbon dating of deep sea sediments: a comparison of accelerator mass spectrometer and beta decay methods. Radiocarbon 31(1):105-16.

Lea DW, Boyle EA. 1990. A 210,000 year record of barium variability in the deep northwest Atlantic ocean. Nature 347:269-72.

McCave IN. 1988. Biological pumping upwards of the coarse fraction of deep-sea sediments. Sedimentary Petrology 58:148-58.

Manighetti B, McCave IN, Maslin M, Schackleton NJ. 1993. Chronology for climate change: developing age models for the Biogeochemical Ocean Flux Study cores. Paleoceanography 10:513-25.

Oehmig R. 1993. Entrainment of planktonic foramin- ifera: effect of bulk density. Sedimentology 40:86977.

Paull CK, Hills SJ, Thiersten HR, Bonani G, Wolfli W. 1991. ${ }^{14} \mathrm{C}$ offsets and apparently non-synchronous $\delta^{18} \mathrm{O}$ stratigraphies between nannofossil and foraminiferal calcites. Quaternary Research 35:274-90.

Peng T-H, Broecker W. 1984. The impacts of bioturbation on the age difference between benthic and planktonic foraminifera in deep sea sediments. Nuclear Instruments and Methods B 5:346-52.

Sanyal A, Hemming NG, Hanson GH, Broecker WS. 1995. Evidence for a higher $\mathrm{pH}$ in the glacial ocean from boron isotopes in foraminifera. Nature 373:2346.

Schiffelbein P, 1984. Effect of benthic mixing on the information content of deep sea stratigraphic signals. Nature 311:651-3.

Schleicher M, Grootes PM, Nadeau M-J, Schoon A. 1998. The carbonate ${ }^{14} \mathrm{C}$ background and its components at the Leibniz AMS facility. Radiocarbon 40(1): 85-93.

Slota PJ Jr, Jull AJT, Linick TW, Toolin LJ. 1987. Preparation of small samples for ${ }^{14} \mathrm{C}$ accelerator targets by catalytic reduction of CO. Radiocarbon 29(2):303-6.

Thomson J, Colley S, Anderson R, Cook GT, MacKenzie AB, Harkness DD. 1993. Holocene sediment fluxes in the northeast Atlantic from ${ }^{230} \mathrm{Th}$ excess and radiocarbon measurements. Palaeoceanography 8:631-50.

Thomson J, Weaver PPE. 1994. An AMS radiocarbon method to determine the emplacement time of recent deep sea turbidites. Sedimentary Geology 89:1-7.

Thomson J, Cook GT, Anderson R, MacKenzie AB, Harkness DD, McCave IN. 1995. Radiocarbon age offsets in different-sized carbonate components of deep-sea sediments. Radiocarbon 37(1):91-101.

Wheatcroft RA, Jumars PA. 1989. Statistical re-analysis for size dependency in deep-sea mixing. Marine Geology 77:157-63. 